\title{
Konsep Transmisi Tidak Koheren menggunakan Differential Unitary Modulation pada OFDMA
}

\section{DHONI PUTRA SETIAWAN, HARFAN HIAN RYANU, VINSENSIUS SIGIT WIDHI PRABOWO}

\author{
Teknik Telekomunikasi, Universitas Telkom, Indonesia \\ Email: setiawandhoni@telkomuniversity.ac.id
}

Received 2 Maret 2021 | Revised 2 April 2021 | Accepted 7 April 2021

\begin{abstract}
ABSTRAK
Differential modulation adalah sebuah teknik modulasi yang memungkinkan pengiriman informasi tanpa diperlukannya estimasi kondisi kanal di sisi penerima. Teknik ini biasa diimplementasikan pada kondisi dimana kanal transmisi berubah dengan sangat cepat, seperti ketika pengguna layanan dalam kondisi mobilitas yang sangat cepat. Pada artikel ini, beberapa teknik differential modulation yang dikembangkan dari Space Time Block Code (STBC) diujicobakan pada Orthogonal Frequency Division Multiple Access (OFDMA) dengan dua skema yang berbeda. Skema pertama menggunakan konsep sistem antena multiple-input multipleoutput (MIMO), dan skema kedua adalah skema single-input single-output (SISO). Hasil pengujian yang diperoleh, teknik differential modulation dengan skema yang ditawarkan pada artikel ini mampu memberikan kinerja yang lebih baik daripada teknik differential modulation yang konvensional. Hasil riset menunjukkan konsep transmisi tidak koheren dapat menjadi solusi potensial untuk sistem komunikasi nirkabel berkecepatan tinggi.
\end{abstract}

Kata kunci: transmisi tidak koheren, differential modulation, mobilitas tinggi, OFDMA, STBC

\begin{abstract}
Differential modulation is a modulation technique that can be used without the presence of channel estimation in the receiver. This technique is usually implemented when the channel condition changes rapidly, for example, when the user is in a high mobility condition. In this paper, several differential modulation techniques, which are modified from space-time block code (STBC) are tested for Orthogonal Frequency Division Multiple Access (OFDMA) using two different schemes. The first scheme uses multiple-input multiple-output (MIMO) antenna system, while the second scheme use single-input single-output (SISO). Based on our results, the differential modulation techniques proposed in this paper can overcome the conventional differential modulation technique. This research shows the proposed non-coherent transmission could be a potential scheme for high mobility wireless communications.
\end{abstract}

Keywords: non-coherent transmission, differential modulation, high mobility, OFDMA, STBC. 


\section{PENDAHULUAN}

Telekomunikasi seluler (telekomunikasi bergerak) berkembang dengan sangat cepat sehingga saat ini telah mencapai generasi $5 \mathrm{G}$ yang merupakan generasi kelima dari komunikasi seluler. 5G pertama kali diluncurkan pada bulan Maret 2019 di Korea dan Amerika Serikat, dan menurut laporan Global mobile Suplier Association pada Februari 2021 sudah ada 61 negara telah mengimplementasikan 5G (Hill, 2021). Standar yang harus dipenuhi suatu teknologi telekomunikasi untuk dapat mengimplementasikan 5G disebut dengan International Mobile Telecommunications-2020 (IMT-2020). Dalam IMT-2020 disebutkan bahwa salah satu persyaratan untuk teknologi yang memenuhi standar $5 \mathrm{G}$ adalah teknologi tersebut harus dapat digunakan pada kecepatan mobilitas mencapai $500 \mathrm{~km} / \mathrm{jam}$, yang merupakan peningkatan dari 350 km/jam yang dipersyaratkan untuk standar 4G (ITU-R, 2017) (Tabbane, 2019).

Tabel 1. Perbandingan 4G dan 5G (ITU-R, 2017) (Tabbane, 2019).

\begin{tabular}{|l|l|l|}
\hline Parameter & IMT-Advanced (4G) & IMT-2020 (5G) \\
\hline Kecepatan Data Maksimal & $1 \mathrm{Gbps}$ & $10 \mathrm{Gbps}$ \\
\hline Latency & $10 \mathrm{~ms}$ & $1 \mathrm{~ms}$ \\
\hline Kepadatan Koneksi & 100.000 perangkat $/ \mathrm{km}^{2}$ & 1.000 .000 perangkat $/ \mathrm{km}^{2}$ \\
\hline Area Traffic Capacity & $0.1 \mathrm{Mbps} / \mathrm{m}^{2}$ & $10 \mathrm{Mbps} / \mathrm{m}^{2}$ \\
\hline Network Energy Efficiency & 1 & $10 \mathrm{kali}$ lipat 4G \\
\hline Efisiensi Spektrum & 1 & $3 \mathrm{kali}$ lipat 4G \\
\hline Mobilitas Maksimum & $350 \mathrm{~km} / \mathrm{jam}$ & $500 \mathrm{~km} / \mathrm{jam}$ \\
\hline
\end{tabular}

Penggunaan komunikasi seluler pada kecepatan tinggi menjadi salah satu komponen persyaratan utama seiring dengan berkembangnya transportasi berkecepatan tinggi seperti kereta cepat. Di sisi lain persyaratan penggunaan pada kecepatan tinggi memang harus dibahas secara khusus pada komunikasi seluler karena menimbulkan masalah baru pada sistem komunikasi seluler, yaitu perubahan kanal komunikasi yang sangat cepat. Perubahan kanal yang sangat cepat ini menjadi masalah karena pada komunikasi koheren yang mengandalkan estimasi kondisi kanal, perubahan respon kanal yang sangat cepat akan mempengaruhi akurasi dari estimasi kondisi kanal. Penambahan pilot untuk menambah akurasi dari kanal akan mengurangi efisiensi pengguna spektrum frekuensi yang digunakan. (Tran, dkk, 2013) (Althunibat, dkk, 2018) (Wen, dkk, 2019).

Untuk mengatasi masalah ini, peneliti menawarkan teknik transmisi tidak koheren yang tidak memerlukan estimasi kondisi kanal, salah satunya adalah teknik differential modulation. Teknik differential modulation sendiri saat ini telah diteliti dan dikembangkan seiring dengan penggunaan multicarrier, coding, dan sistem antena multiple-input multiple-output (MIMO) untuk meningkatkan kinerja sistem seperti teknik Differential Space Time Block Code (Ganesan \& Stoica, 2002) (Kumar, dkk, 2014), Differential Unitary Modulation , dan juga Differential Unitary Space Time Frequency (DUSTF) (Tran, dkk, 2013) (Setiawan \& Zhao, 2019). Selain diterapkan pada komunikasi nirkabel, differential modulation juga diteliti penggunaannya untuk komunikasi menggunakan fiber optic (Sotiropoulos, dkk, 2013).

Pada artikel ini, kami membahas penggunaan teknik differential modulation untuk digunakan pada sistem Orthogonal Frequency Division Multiple Access (OFDMA). Kami membahas ini karena didasari fakta bahwa pada penelitian-penelitian yang telah ada sebelumnya, sebagian besar sistem transmisi diasumsikan sebagai sistem pengguna tunggal, sedangkan pada kenyataannya di 4G ataupun 5G sistem yang digunakan adalah sistem pengguna jamak menggunakan OFDMA (Tabbane, 2019). Sebuah artikel oleh (Hofer, dkk, 2013) memang 
membahas differential modulation dengan konsep OFDMA tetapi masih menggunakan konsep differential modulation yang masih konvensional. Pada artikel tersebut differential modulation konvensional membutuhkan Signal to Noise Ratio (SNR) 2 dB lebih besar untuk mencapai throughput yang sama dengan transmisi koheren. Pada artikel oleh (Alsifiany, dkk, 2017) meskipun membahas differential modulation untuk pengguna jamak tetapi tidak menggunakan OFDMA. Pada artikel tersebut kinerja dari differential modulation juga membutuhkan SNR 2 $\mathrm{dB}$ lebih besar untuk mencapai Bit Error Rate (BER) yang sama dengan transmisi koheren. Pada artikel ini kami menyajikan beberapa teknik penerapan differential modulation yang dipadukan dengan Space Time Block Code (STBC) pada OFDMA untuk meningkatkan kinerja dari teknik differential modulation meskipun sistem transmisi tidak menggunakan teknik MIMO.

Pada artikel ini kami menggunakan teknik Differential Unitary Modulation yang menggunakan unitary matrix generator yang telah dikembangkan dalam beberapa peneltian sebelumnya, seperti penggunaan STBC Alamouti pada (Tran, dkk, 2013) dan QO-STBC pada (Setiawan \& Zhao, 2019). Kami juga memodifikasi Orthogonal STBC untuk empat antena pemancar pada artikel (Ganesan \& Stoica, 2002) untuk dapat digunakan pada sistem multicarrier. Teknik-teknik ini kemudian kami bandingkan dengan differential modulation yang konvensional. Pada artikel ini kami mengasumsikan bahwa transmitter mampu mengolah setiap simbol yang akan ditempatkan pada tiap-tiap resource block secara independent antara satu resource block dengan resource block lain sehingga memungkinkan transmitter untuk memberikan perlakuan berbeda tergantung kondisi dari penerima. Hal ini memungkinkan dapat diaplikasikan pada sistem komunikasi kini dan mendatang karena konsep virtual baseband unit (vBBU) yang mulai banyak diterapkan saat ini memungkinkan untuk memberikan baseband unit (BBU) lebih banyak fleksibilitas dalam mengolah informasi yang akan dikirimkan (Gavrilovska, dkk, 2017) (Checko, dkk, 2015).

\section{MODEL SISTEM}

\subsection{Differential modulation}

Differential modulation adalah sebuah teknik transmisi yang memanfaatkan simbol yang telah dikirimkan sebelumnya sebagai simbol referensi. Differential modulation biasanya menggunakan Phase Shift Keying (PSK) sebagai Modulator atau Mapper (pada multicarrier), meskipun saat ini beberapa konsep differential modulation yang menggunakan jenis modulasi lain seperti Amplitude and Phase Shift Keying (APSK), Quadrature Amplitude Modulation (QAM), telah diteliti, meskipun dengan tingkat kompleksitas yang lebih tinggi dibandingkan menggunakan PSK (Martin, 2015) (Wei \& Wang, 2018) (Kumar, dkk, 2014). Gambaran proses pada sisi transmitter dari differential modulation dapat dilihat pada Gambar 1 berikut:

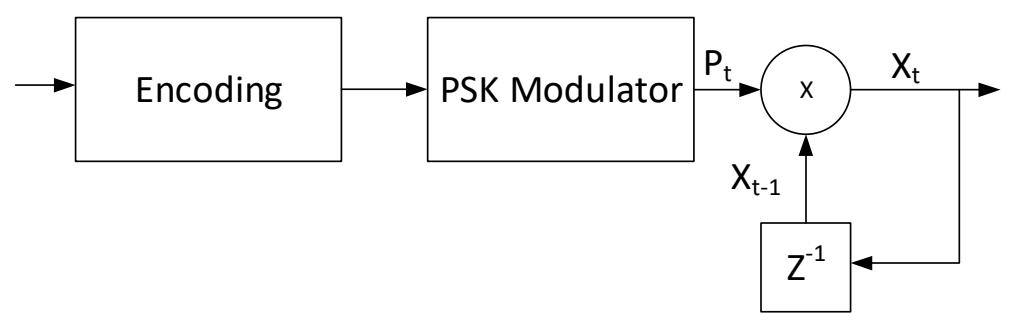

Gambar 1. Blok diagram differential modulation konvensional.

Dari sistem pada Gambar 1 berlaku: $X_{t}=P_{t} X_{t-1}$, dimana $P_{t}$ adalah simbol keluaran dari PSK Modulator, dan $X_{t}$ adalah hasil perkalian antara $P_{t}$ dan $X_{t}$ yang dikirimkan pada periode transmisi sebelumnya atau disebut dengan $X_{t-1}$. 


\subsection{Differential Unitary Modulation}

Untuk sistem multicarrier dan MIMO, differential modulation seperti pada sub-bab 2.1 dikembangkan dengan penggunaan unitary generator, sehingga simbol tidak lagi diproses satu persatu tetapi diproses dalam satu set seperti yang telah ditawarkan konsepnya oleh Tran (Tran, dkk, 2013) (Setiawan \& Zhao, 2019). Unitary generator pada beberapa artikel tersebut dibentuk dengan penggunaan Space Time Coding sehingga unitary generator tidak hanya berfungsi untuk mengefisienkan proses tetapi juga untuk mendapatkan space diversity dan time diversity. Bagan proses yang terjadi pada transmitter digambarkan pada gambar berikut ini:

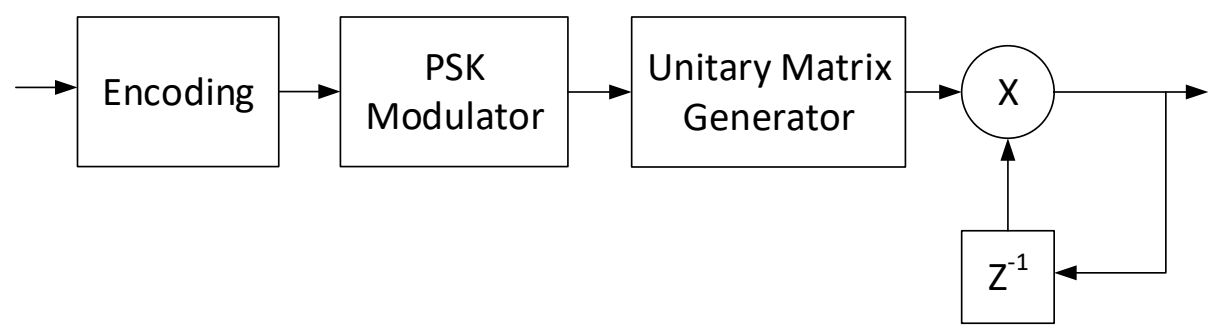

Gambar 2. Blok diagram Differential Unitary Modulation.

Pada Gambar 2 dapat dilihat bahwa keluaran dari PSK modulator tidak langsung dilakukan proses perkalian, tetapi dikelompokkan terlebih dahulu oleh Unitary Matrix Generator. Setelah terbentuk satu kelompok simbol dalam sebuah Unitary Matrix, kelompok simbol ini lantas akan dikalikan dengan kelompok simbol yang sebelumnya ditransmisikan.

\subsection{Differential Unitary Modulation untuk OFDMA}

OFDMA adalah sebuah teknik pengguna jamak yang membagi-bagi alokasi subcarrier kepada pengguna. Pada LTE, subcarrier atau juga disebut juga resource element, dikelompokkan menjadi sebuah resource block, dengan komposisi sebuah resource block berisi 12 buah subcarrier. Artikel-artikel yang sebelumnya membahas mengenai differential modulation biasanya hanya membahas mengenai penggunaan pada OFDM atau teknik modulasi subcarrier lain, sangat sedikit ke arah multiple access tertentu. Hal ini wajar mengingat di masa lampau blok yang bertugas mengolah sinyal yang akan ditransmisikan ke antena, yang pada 4G dinamakan dengan baseband unit (BBU) biasanya hanya mampu melakukan satu macam signal processing saja untuk sinyal yang dikirimkan ke seluruh pengguna. Akan tetapi, dengan teknologi yang ada saat ini, yang ditunjang dengan virtualisasi pada BBU perbedaan signal processing antara satu pengguna dan pengguna yang lain sangat mungkin untuk diimplementasikan.

\subsubsection{Skema 1}

Pada penelitian ini dibahas dua buah skema differential modulation, dimana skema yang pertama dapat dilihat pada Gambar 3. 


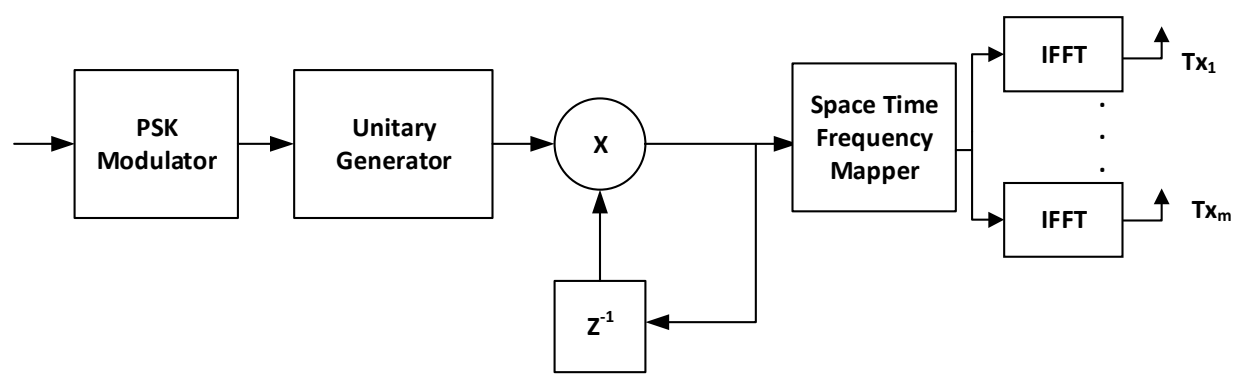

Gambar 3. Blok diagram Differential Unitary Modulation dengan Skema 1.

Skema yang pertama ini, menyerupai skema DUSTF pada pengguna tunggal biasa, tetapi kami mengasumsikan bahwa pengguna hanya mendapatkan satu buah resource block saja untuk setiap antena pemancar yang dimiliki oleh transmitter. Apabila antena yang dimiliki transmitter adalah dua buah antena maka total setiap pengguna akan mendapatkan slot dua resource block, dan apabila antena yang dimiliki transmitter adalah empat buah antena maka total setiap pengguna akan mendapatkan slot empat buah resource block.

Unitary matrix generator yang digunakan untuk transmitter yang memiliki dua antena pemancar adalah sebagai berikut:

$$
S_{t}=\frac{1}{\sqrt{2}}\left[\begin{array}{cc}
\operatorname{diag}\left(s_{t, 1}\right) & \operatorname{diag}\left(s_{t, 2}\right) \\
\operatorname{diag}\left(-s_{t, 2}^{*}\right) & \operatorname{diag}\left(s_{t, 1}^{*}\right)
\end{array}\right]
$$

Formula ini dimodifikasi dari STBC Alamouti, dimana $S_{t}$ adalah unitary matrix yang merupakan keluaran dari unitary matrix generator, dan $s_{t, m}$ adalah sebuah column matrix berukuran (12 x 1), dimana komponen dari $s_{t, m}$ keluaran dari PSK modulator yang disusun ke dalam $s_{t, m}$ seperti berikut $\mathbf{s}_{t, m}=\left[s_{t, m, 1} s_{t, m, 2} \ldots s_{t, m, 12}\right]$. Angka 12 pada ukuran column matrix didapatkan dari jumlah subcarrier yang ada di dalam satu resource block. Proses diagonalisasi matrix $s_{t, m}$ dilakukan agar matrix $S_{t}$ menjadi square matrix. Formula ini telah digunakan pada artikel (Tran, dkk, 2013), tetapi dengan asumsi bahwa ukuran matrixnya sama dengan total jumlah subcarrier. Teknik Differential modulation ini pada artikel ini kami sebut dengan Differential Unitary Modulation dengan STBC Alamouti.

Untuk unitary matrix generator yang digunakan pada transmitter yang memiliki empat buah antena pemancar kami meneliti dua macam matrix generator, yang pertama adalah sebagai berikut:

$$
S_{t}=1 / \sqrt{3}\left[\begin{array}{cccc}
\operatorname{diag}\left(s_{t .1}\right) & 0_{12 \times 12} & \operatorname{diag}\left(s_{t .2}\right) & \operatorname{diag}\left(-s_{t .3}\right) \\
0_{12 \times 12} & \operatorname{diag}\left(s_{t .1}\right) & \operatorname{diag}\left(s_{t .3}{ }^{*}\right) & \operatorname{diag}\left(s_{t .2}{ }^{*}\right) \\
\operatorname{diag}\left(-s_{t .2}\right) & \operatorname{diag}\left(-s_{t .3}\right) & \operatorname{diag}\left(s_{t .1}{ }^{*}\right) & 0_{12 \times 12} \\
\operatorname{diag}\left(s_{t .3}{ }^{*}\right) & \operatorname{diag}\left(-s_{t .2}\right) & 0_{12 \times 12} & \operatorname{diag}\left(s_{t .1}{ }^{*}\right)
\end{array}\right]
$$

Matrix Generatorini dimodifikasi dari orthogonal STBC(OSTBC) untuk empat antena pemancar yang ditawarkan oleh (Ganesan \& Stoica, 2002) pada konsep Differential Unitary Modulation dengan empat antena pemancar yang mereka tawarkan, sehingga konsep ini dapat cocok digunakan pada transmisi multicarrier. Pada artikel ini, teknik differential modulation ini kami sebut dengan Differential Unitary Modulation dengan OSTBC. Konsep ini akan tetapi memiliki kelemahan yaitu bukan merupakan full rate STBC, tidak seperti STBC Alamouti. Kondisi ini akan mengurangi efisiensi spektrum frekuensi dari sistem transmisi ini. 
Oleh karena itu disini kami turut meneliti penggunaan modifikasi Quasi-Orthogonal STBC(QOOSTBC) sebagai unitary matrix generator seperti yang pernah ditawarkan pada artikel (Setiawan \& Zhao, 2019).

$$
\mathbf{S}_{t}=1 / \sqrt{8}\left[\begin{array}{c}
\operatorname{diag}\left(s_{t, 1}+s_{t, 2}\right) \operatorname{diag}\left(s_{t, 3}+s_{t, 4}\right) \operatorname{diag}\left(s_{t, 1}-s_{t, 2}\right) \operatorname{diag}\left(s_{t, 3}-s_{t, 4}\right) \\
\operatorname{diag}\left(-s_{t, 3}^{*}-s_{t, 4}^{*}\right) \operatorname{diag}\left(s_{t, 1}^{*}+s_{t, 2}^{*}\right) \operatorname{diag}\left(s_{t, 4}^{*}-s_{t, 3}^{*}\right) \operatorname{diag}\left(s_{t, 1}^{*}-s_{t, 2}^{*}\right) \\
\operatorname{diag}\left(s_{t, 1}-s_{t, 2}\right) \operatorname{diag}\left(s_{t, 3}-s_{t, 4}\right) \operatorname{diag}\left(s_{t, 1}+s_{t, 2}\right) \operatorname{diag}\left(s_{t, 3}+s_{t, 4}\right) \\
\operatorname{diag}\left(s_{t, 4}^{*}-s_{t, 3}^{*}\right) \operatorname{diag}\left(s_{t, 1}^{*}-s_{t, 2}^{*}\right) \operatorname{diag}\left(-s_{t, 3}^{*}-s_{t, 4}^{*}\right) \operatorname{diag}\left(s_{t, 1}^{*}+s_{t, 2}^{*}\right)
\end{array}\right] \text {. }
$$

Menurut (Setiawan \& Zhao, 2019) penggunaan unitary matrix dari QO-STBC tersebut mampu memberikan efisiensi spektrum frekuensi yang lebih baik dan juga total kompleksitas sistem yang lebih rendah karena bisa memproses lebih banyak simbol dalam satu kali transmisi, meskipun kinerjanya sedikit lebih buruk daripada OSTBC untuk empat antena pemancar. Pada artikel ini, teknik differential modulation ini kami sebut dengan Differential Unitary Modulation dengan QO-STBC.

Keluaran dari unitary matrix yang sudah disusun kemudian dikalikan dengan kelompok unitary matrix yang telah dikirimkan sebelumnya sehingga membentuk hubungan:

$$
U_{t}=S_{t} U_{t-1}
$$

dimana $U_{t}$ adalah keluaran dari perkalian antara $S_{t}$ dengan $U_{t}$ pada periode sebelumnya $\left(U_{t-1}\right)$. Proses perkalian inilah yang disebut dengan proses diferensiasi pada konsep differential modulation. Berikutnya komponen dari $U_{t}$ akan dipetakan ke dalam resource block yang berada pada masing-masing sistem transmisi antena. Contohnya pada sistem Differential Unitary Modulation dengan STBC Alamouti, Matriks $U_{t}$ dapat dijabarkan sebagai berikut:

$$
U_{t}=\left[\begin{array}{cc}
\operatorname{diag}\left(u_{t, 1}\right) & \operatorname{diag}\left(u_{t, 2}\right) \\
\operatorname{diag}\left(-u_{t, 2}^{*}\right) & \operatorname{diag}\left(u_{t, 1}^{*}\right)
\end{array}\right] .
$$

Komponen dari $U_{t}$ yaitu $u_{t, m}$ akan dipetakan untuk ditransmisikan pada dua antena berbeda dan dua timeslot berbeda. Pada differential modulation dengan empat antena transmisi komponen matriks akan dikirimkan pada empat antena berbeda dan pada empat timeslot berbeda.

\subsubsection{Skema 2}

Blok diagram dari skema kedua dapat dilihat pada Gambar 4 berikut ini:

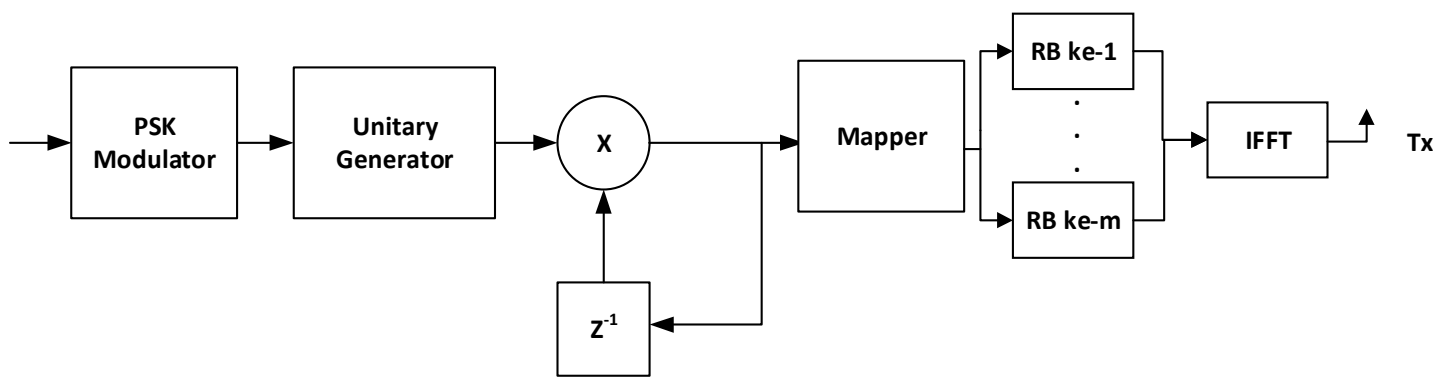

Gambar 4. Blok diagram Differential Unitary Modulation dengan Skema 2. 
Skema 2 pada dasarnya menggunakan teknik differential modulation yang sama dengan yang digunakan pada skema 1 yaitu Differential Unitary Modulation dengan STBC Alamouti, Differential Unitary Modulation dengan OSTBC, dan Differential Unitary Modulation dengan QO-STBC. Pada skema 2 ini diasumsikan semua sistem hanya memiliki satu buah transmitter saja, tetapi meskipun hanya memiliki 1 transmitter, unitary matrix generator yang digunakan pada skema 1 (formula (1), (2), dan (3)) dapat diimplementasikan pada skema 2. Caranya yang dilakukan adalah dengan mengubah pemetaan simbol yang pada skema 1 ditransmisikan ke beberapa antena berbeda, menjadi ditransmisikan ke beberapa resource block berbeda yang masih dalam satu unit antena pemancar. Skema ini memungkinkan perbaikan kinerja karena efek diversity, meskipun kemiripan kanal transmisi antar resource block yang ada pada skema dua akan memberikan hasil kinerja yang lebih buruk dibandingkan dengan skema 1 yang antara antena satu dan lainnya memiliki jalur transmisi tersendiri sehingga nilai diversity yang bisa didapat lebih maksimal. Meskipun demikian, skema 2 memiliki kelebihan, yaitu skema ini dapat diimplementasikan meskipun transmitter hanya memiliki satu buah antena pemancar saja.

\subsubsection{Proses Decoding}

Simbol yang diterima oleh receiver setelah proses FFT (demodulasi OFDM) dapat dituliskan sebagai berikut:

$$
Y_{t}=U_{t} \circ H_{t}+N,
$$

dimana $Y_{t}$ adalah set matrix yang diterima, $H_{t}$ adalah respon kanal transmisi, dan $N$ adalah Noise. Untuk mendapatkan nilai $\widehat{U}_{t}$ kembali, yang merupakan $U_{t}$ hasil decoding pada sisi receiver maka digunakan formula berikut:

$$
\widehat{U}_{t}=Y_{t} Y_{t-1}^{H}
$$

dimana $Y_{t-1}^{H}$ adalah nilai transpose conjugate dari $Y_{t-1}$.

\section{PENGUJIAN}

\subsection{Skenario Pengujian}

Pengujian sistem menggunakan perangkat lunak Matlab R2018a dengan parameter pengujian yang tertera pada tabel berikut ini:

Tabel 2. Parameter Pengujian

\begin{tabular}{|l|l|}
\hline Parameter & Nilai \\
\hline Jumlah Bit yang dikirim & 5.000 .000 bit \\
\hline Frekuensi & $2,3 \mathrm{GHz}$ \\
\hline Cyclic Prefix & $25 \%$ \\
\hline Mapper & BPSK \\
\hline Modulator & OFDM \\
\hline Kecepatan & $350 \mathrm{~km} / \mathrm{jam}$ \\
\hline Model Kanal & Rayleigh \\
\hline
\end{tabular}


Frekuensi pembawa yang kami pilih disini adalah $2,3 \mathrm{GHz}$ yang merupakan frekuensi yang digunakan baik pada LTE dan juga telah distandarisasi oleh 3GPP untuk 5G New Radio (5GNR). Kinerja yang diukur pada penelitian ini adalah nilai BER yang dibandingkan dengan nilai Signal to Noise Ratio (SNR).

\subsection{Hasil Pengujian}

\subsubsection{Hasil Pengujian Skema 1}

Pada pengujian yang pertama, kami membandingkan kinerja dari Differential Unitary Modulation dengan STBC Alamouti, Differential Unitary Modulation dengan OSTBC, dan Differential Unitary Modulation dengan QO-STBC Matrix dengan menggunakan skema 1. Ketiga teknik ini kami bandingkan kinerjanya dengan differential modulation yang konvensional yang pada artikel ini disebut dengan Conventional Differential Modulation untuk mengetahui berapa banyak gain yang bisa didapatkan skema yang kami teliti dibandingkan dengan skema Conventional Differential Modulation. Hasil dari pengujian dapat dilihat pada Gambar 5.

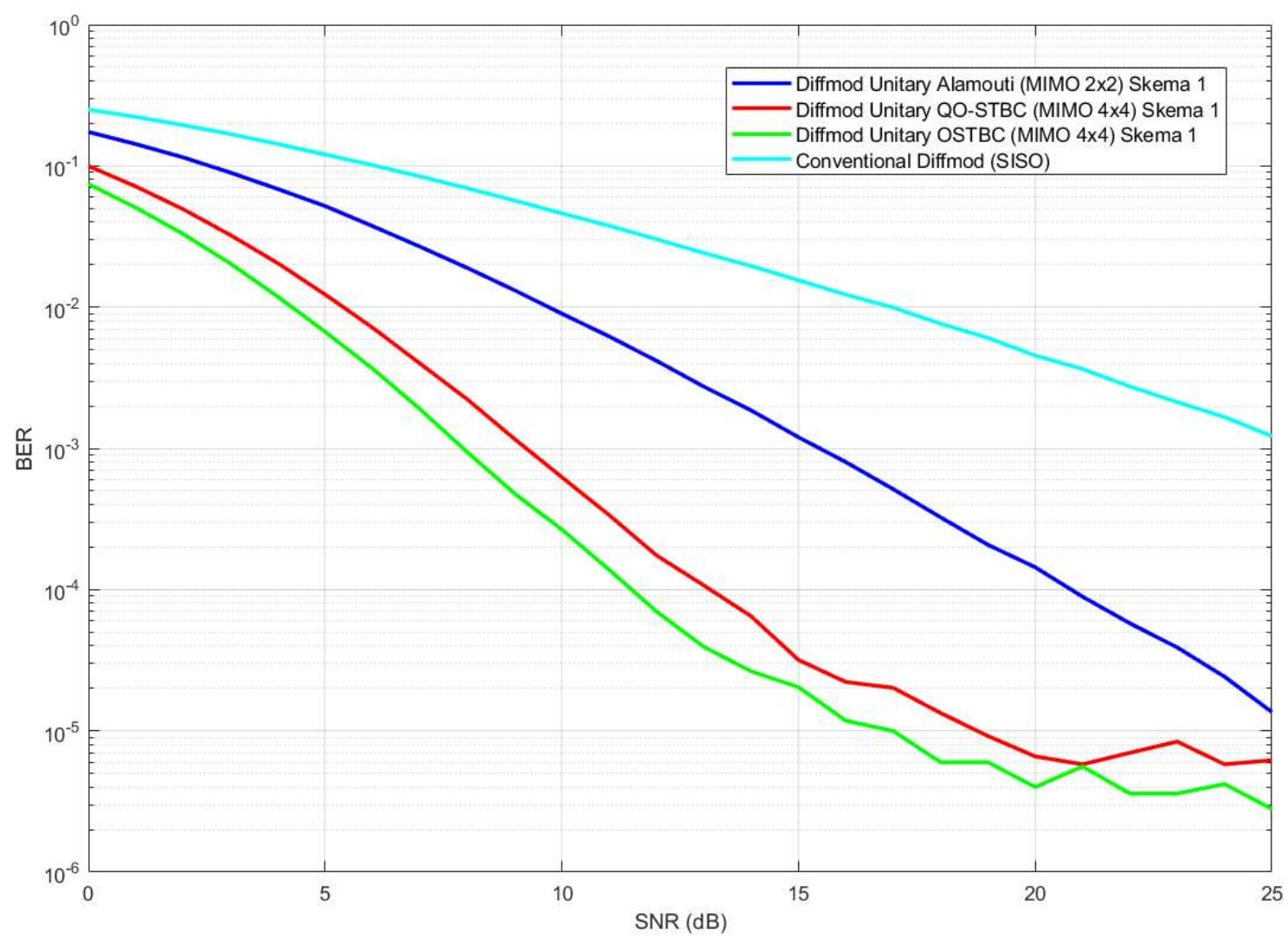

Gambar 5. Hasil Pengujian dengan Skema 1.

Secara umum dari Gambar 5 bisa dilihat bahwa Differential Unitary Modulation dengan OSTBC memiliki kinerja paling baik diantara seluruh skema yang diuji. Hal ini bisa terlihat dari kebutuhan nilai SNR yang paling rendah untuk mencapai nilai BER yang sama dengan teknik differential modulation yang lain. Kinerja dari Differential Unitary Modulation dengan OSTBC Matrix dapat didekati oleh Differential Unitary Modulation dengan QO-STBC Matrix, dengan perbedaan nilai SNR kurang lebih hanya $1,3 \mathrm{~dB}$ pada saat nilai BER adalah $10^{-3}$. Pada grafik ini dapat dilihat juga bahwa seluruh teknik differential modulation yang diteliti di artikel ini 
memiliki kinerja lebih baik daripada Conventional Differential Modulation. Conventional Differential Modulation membutuhkan nilai SNR lebih dari $25 \mathrm{~dB}$ untuk mendapatkan BER $10^{-3}$ dibandingkan dengan 15,5 dB yang dibutuhkan oleh Differential Unitary Modulation dengan STBC Alamouti, 14,3 dB yang dibutuhkan oleh Differential Unitary Modulation dengan QOSTBC, dan $13 \mathrm{~dB}$ yang dibutuhkan oleh Differential Unitary Modulation dengan OSTBC Matrix. Secara umum dari hasil simulasi pengujian ini dapat kita lihat bahwa pengaruh sistem antena MIMO memang berdampak besar pada kinerja dari sistem, kedua teknik yang menggunakan sistem MIMO 4x4 memiliki kinerja paling baik, dibandingkan MIMO 2x2 dan SISO, sedangkan sistem yang menggunakan MIMO 2x2 memiliki kinerja yang lebih baik daripada SISO. Meskipun Differential Unitary Modulation dengan QO-STBC disini memiliki kinerja yang lebih buruk dibandingkan dengan OSTBC, tetapi ada dua hal yang menjadi kelebihan teknik ini yaitu: QO-STBC memiliki efisiensi spektrum yang lebih tinggi $0,25 \mathrm{bits} / \mathrm{Hz}$ berbanding $0,1875 \mathrm{bits} / \mathrm{Hz}$ dan juga memiliki waktu running program yang lebih singkat 890 detik berbanding 1.165 detik, yang menandakan nilai kompleksitas yang lebih rendah.

\subsubsection{Hasil Pengujian Skema Dua}

Pada skema dua, Differential Unitary Modulation dengan STBC Alamouti, Differential Unitary Modulation dengan OSTBC, dan Differential Unitary Modulation dengan QO-STBC diuji kinerjanya dengan dibandingkan dengan Conventional Differential Modulation.

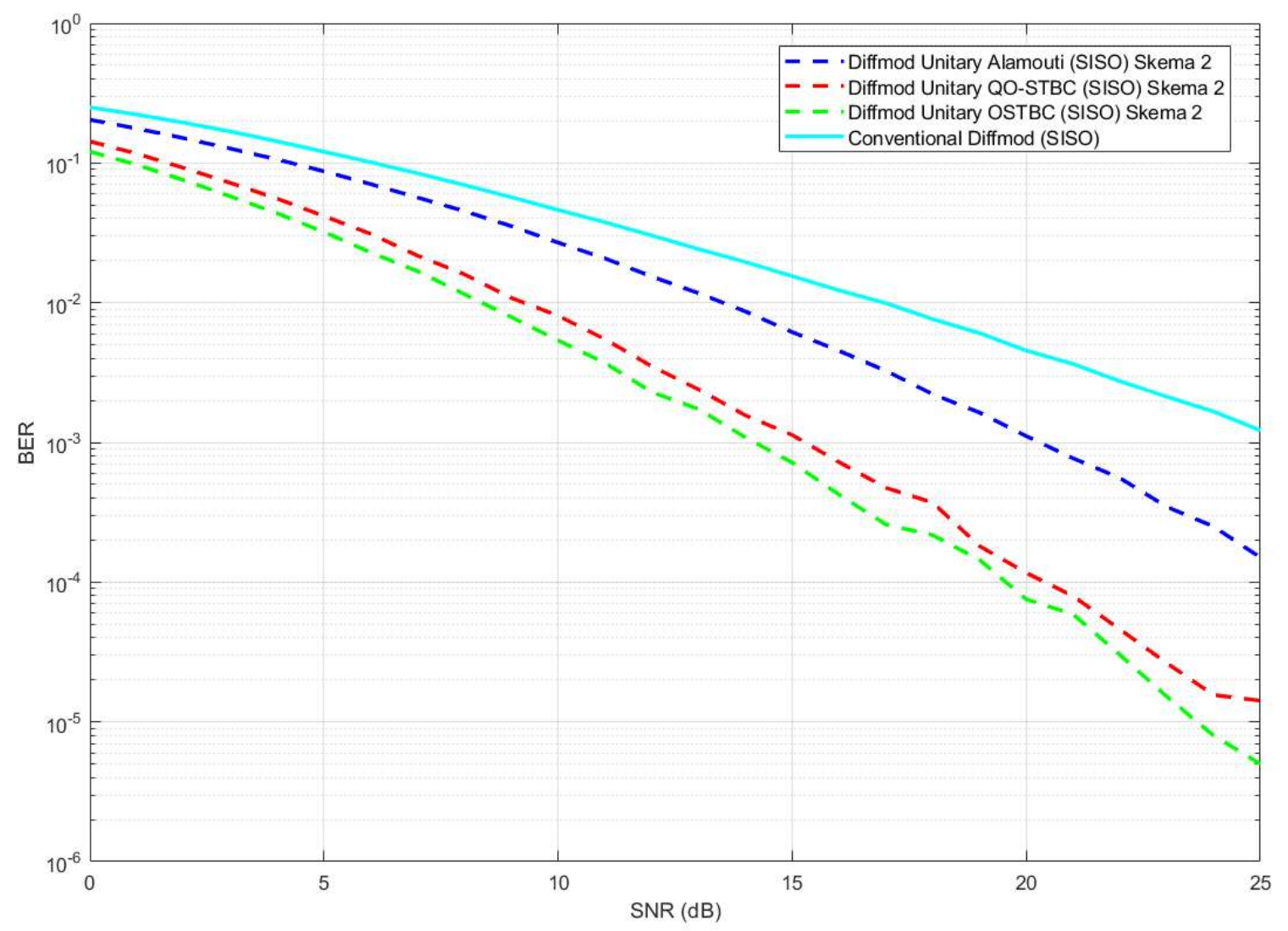

Gambar 6. Hasil pengujian dengan Skema 2.

Sesuai hasil pengujian pada Gambar 6, secara umum urutan hasil kinerja dari teknik-teknik differential modulation yang diuji pada pengujian kedua ini memiliki persamaan dengan skema 
1. Differential Unitary Modulation dengan OSTBC masih merupakan teknik differential modulation dengan kinerja paling baik, disusul secara berturut-turut oleh Differential Unitary Modulation dengan QO-STBC, Differential Unitary Modulation dengan STBC Alamouti, dan yang paling buruk kinerjanya adalah Conventional Differential Modulation. Meskipun memiliki urutan kinerja yang sama, secara umum perbedaan kinerja antara satu teknik dengan yang lainnya tidaklah memilki perbedaan yang besar, seperti perbedaan antara Differential Unitary Modulation dengan OSTBC dan dengan QO-STBC hanya memiliki selisih kurang dari $1 \mathrm{~dB}$ pada nilai BER berapapun. Perbedaan kinerja yang semakin kecil ini pada dasarnya didasari oleh penurunan kinerja dari seluruh teknik differential modulation pada skema dua ini, yang detailnya bisa dilihat pada sub-bab 3.2.3.

\subsubsection{Perbandingan Skema 1 dan Skema 2}

Pada Sub-bab ini hasil yang diperoleh pada skema 1 dan skema 2 dibandingkan untuk mengetahui perbandingan nilai kinerja antara kedua skema yang kami tawarkan pada artikel ini.

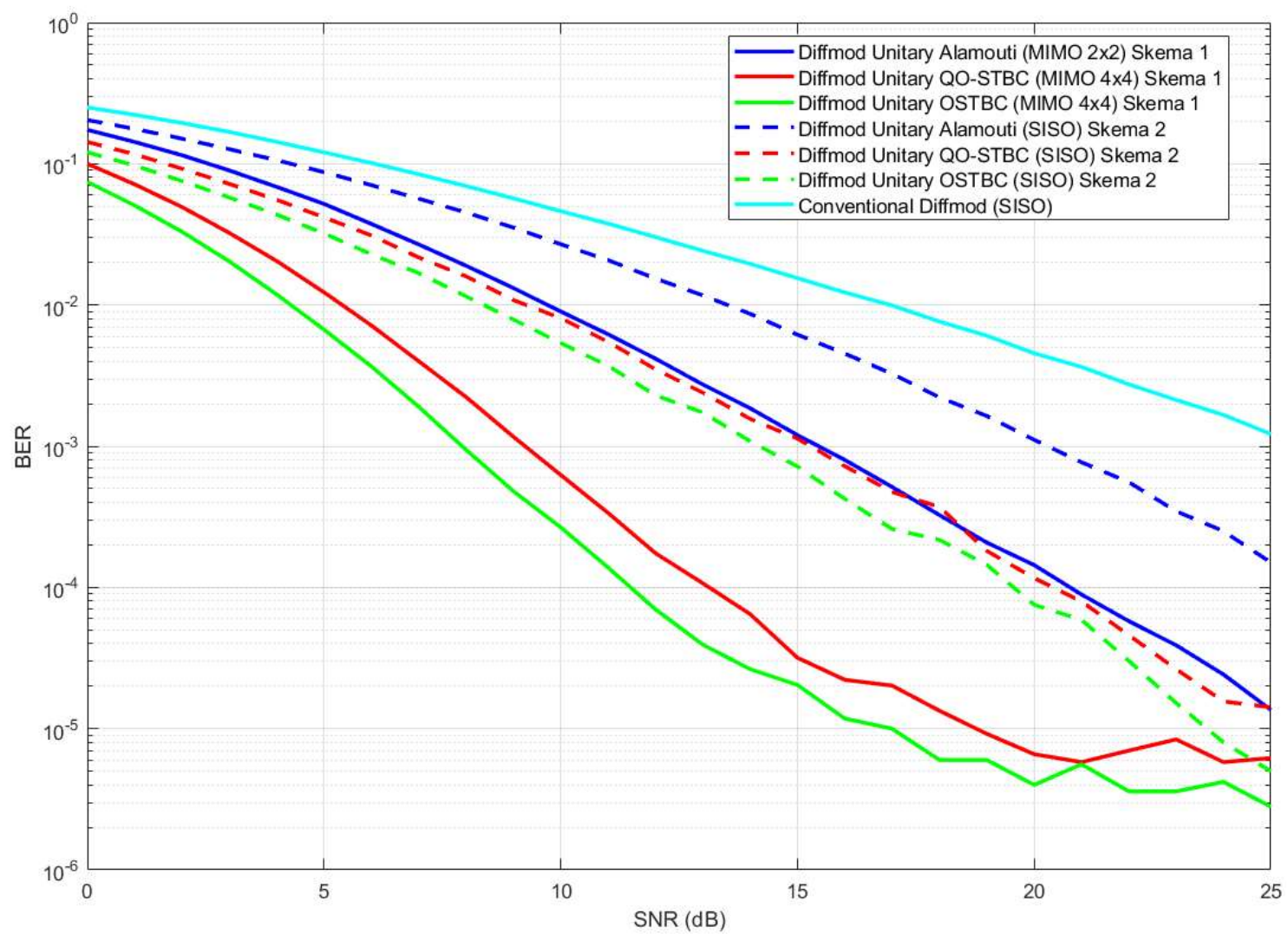

Gambar 7. Perbandingan hasil Skema 1 dan Skema 2.

Dari Gambar 7, dapat disimpulkan bahwa kinerja teknik-teknik differential modulation yang diaplikasikan pada skema 1 lebih unggul daripada differential modulation yang diaplikasikan pada skema 2. Hal ini dapat terjadi karena penggunaan sistem MIMO pada antena 1 dimana setiap kanal diatur independen terhadap kanal lain, menjadikan nilai diversity gain dari skema 1 menjadi lebih optimal daripada pada skema 2 yang hanya menggunakan skema SISO. Meskipun pada skema 2 simbol dipetakan pada beberapa resource block berbeda, tetapi kemiripan kanal antara resource block yang akan ditransmisikan pada antena yang sama 
membuat diversity gain yang didapat tidak maksimal. Meskipun demikian skema 2 yang hanya menggunakan satu buah transmitter saja tentu memiliki keunggulan dalam sisi kompleksitas sistem yang akan berakibat pada biaya fabrikasi yang lebih murah dan juga penggunaan daya yang lebih efisien.

\subsubsection{Perbandingan dengan Convolutional Differential Modulation}

Pada skenario pengujian yang terakhir ini kinerja dari Differential Unitary Modulation dengan STBC Alamouti yang tanpa menggunakan channel coding, dibandingkan dengan Conventional Differential Modulation yang menggunakan channel coding yaitu convolutional coding dengan rate $1 / 2$ ditambah dengan interleaver. Kami membandingkan ini hanya dengan Differential Unitary Modulation dengan STBC Alamouti, karena keduanya memiliki efisiensi spektrum yang sama yaitu 0,5 bit/Hz. Dengan membandingkan keduanya kami ingin mengetahui mana yang memberikan kinerja sistem lebih baik antara Differential Unitary Modulation dengan Alamouti Matrix yang tidak menggunakan channel coding, atau Conventional Differential Modulation yang menggunakan channel coding dan interleaver.

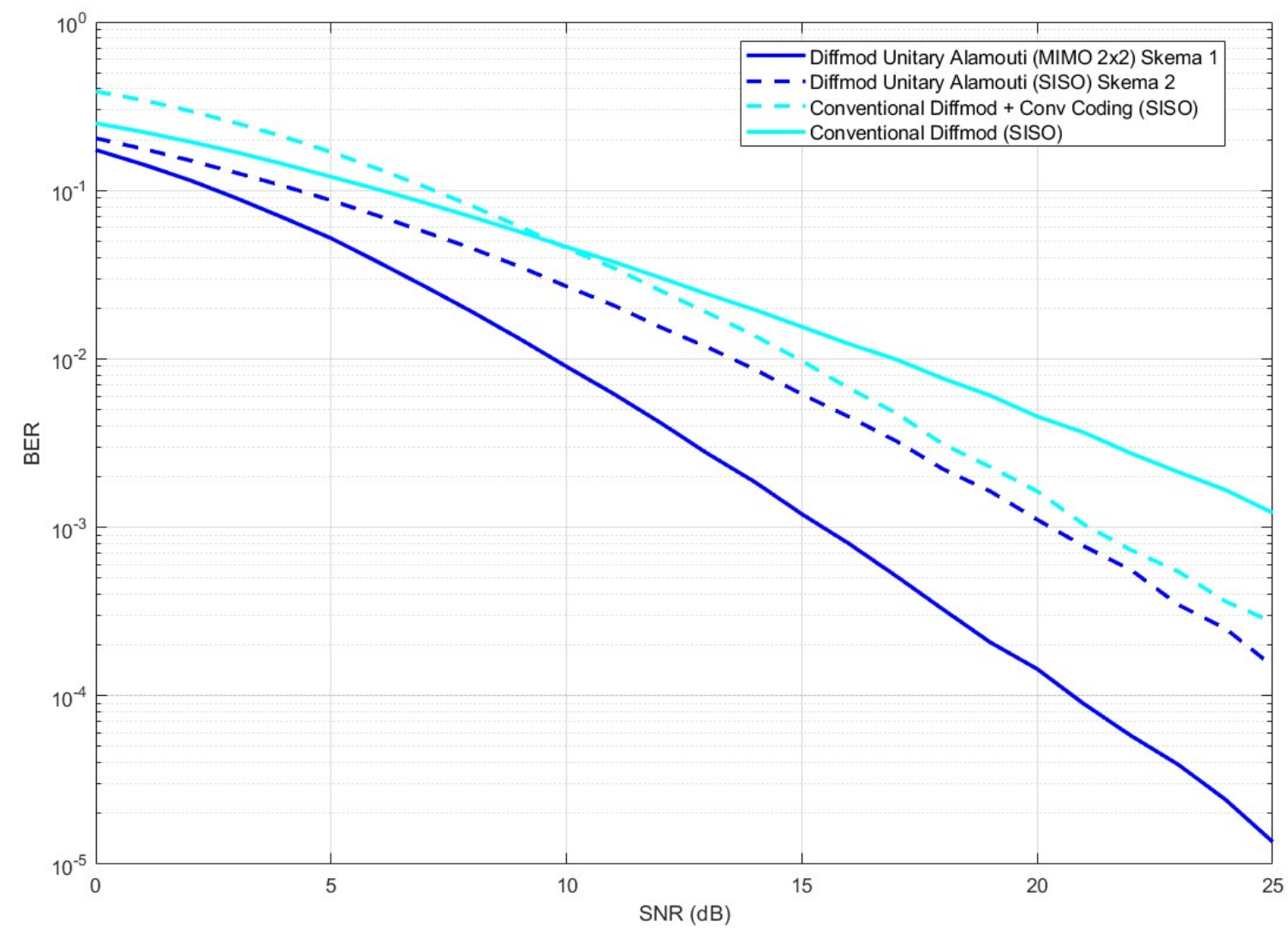

Gambar 8. Perbandingan Differential Unitary Modulation dengan STBC Alamouti dan Conventional Differential Modulation dengan coding.

Dari Gambar 8, dapat disimpulkan bahwa Differential Unitary Modulation dengan STBC Alamouti baik menggunakan skema 1 atau skema 2 memiliki kinerja yang lebih superior dibandingkan dengan Conventional Differential Modulation baik yang menggunakan channel coding maupun tidak. Differential Unitary Modulation dengan STBC Alamouti pada skema 2 yang juga menggunakan skema antena SISO juga berhasil mengungguli kinerja dari Conventional Differential Modulation dengan convolutional coding meskipun dengan selisih 
hanya sekitar $1 \mathrm{~dB}$ pada BER $10^{-3}$. Perbandingan lebih mendetail dapat dilihat pada Tabel 3 dibawah ini.

Tabel 3. Tabel Perbandingan Differential Unitary Modulation dengan STBC Alamouti dan Conventional Differential Modulation dengan coding.

\begin{tabular}{|l|l|l|l|}
\hline Parameter & $\begin{array}{l}\text { Diffmod Unitary } \\
\text { Alamouti Skema 1 }\end{array}$ & $\begin{array}{l}\text { Diffmod Alamouti Skema 2 } \\
\text { Alary }\end{array}$ & $\begin{array}{l}\text { Conventional } \\
\text { Diffmod } \\
\text { Coding }\end{array}$ \\
\hline Skema Antena & MIMO 2x2 & SISO & SISO \\
\hline Efisiensi Spektrum & $0,5 \mathrm{bit} / \mathrm{Hz}$ & $0,5 \mathrm{bit} / \mathrm{Hz}$ & $0,5 \mathrm{bit} / \mathrm{Hz}$ \\
\hline $\begin{array}{l}\text { Rata-rata waktu running } \\
\text { pada Matlab }\end{array}$ & $728 \mathrm{detik}$ & $653 \mathrm{detik}$ & $1178 \mathrm{detik}$ \\
\hline SNR pada BER $10^{-2}$ & $9,8 \mathrm{~dB}$ & $13,7 \mathrm{~dB}$ & $14,9 \mathrm{~dB}$ \\
\hline SNR pada BER $10^{-3}$ & $15,5 \mathrm{~dB}$ & $20,3 \mathrm{~dB}$ & $21,1 \mathrm{~dB}$ \\
\hline
\end{tabular}

Pada Tabel 3 waktu running program dari ketiga skema kami bandingkan untuk mengetahui nilai kompleksitas dari setiap sistem. Waktu running yang lama menunjukkan bahwa sistem memiliki nilai kompleksitas yang lebih besar daripada sistem yang memiliki waktu running lebih pendek. Skema differential unitary modulation yang kami bandingkan ini telah dioptimasi menggunakan skema low complexity differential modulation yang ditawarkan pada (Setiawan \& Zhao, 2018). Dari data waktu running didapatkan bahwa Differential Unitary Modulation dengan STBC Alamouti pada skema 2 memiliki waktu running yang paling singkat, disusul Differential Unitary Modulation dengan STBC Alamouti pada skema 1 yang meskipun menggunakan sistem differential yang sama, tetapi karena sinyal harus dikirimkan pada 2 antena pemancar yang berbeda, sehingga nilai kompleksitas sistemnya menjadi lebih tinggi. Conventional Differential Modulation dengan channel coding memiliki waktu running yang paling lama yang menandakan kompleksitas sistemnya paling tinggi, meskipun secara kinerja adalah yang paling buruk dibandingkan dengan 2 skema yang lain.

\section{KESIMPULAN}

Pada artikel ini, beberapa tipe differential modulation untuk OFDMA dibandingkan kinerjanya dengan dua skema yang berbeda. Pada skema 1 simbol yang akan dikirim dipetakan pada resource block yang terletak pada beberapa antena pemancar berbeda sedangkan skema 2 seluruhnya menggunakan antena tunggal. Hasil penelitian menunjukkan kinerja teknik-teknik differential modulation pada skema 1 lebih baik kinerjanya daripada pada skema 2 dengan selisih nilai kebutuhan SNR mencapai $5 \mathrm{~dB}$ pada BER $10^{-3}$ untuk setiap skema differential modulation yang sama. Hal ini dikarenakan sistem MIMO yang digunakan skema 1 mampu memberikan diversity gain yang lebih baik karena kanal transmisi yang independen satu dengan yang lain daripada skema 2 yang setiap kanalnya memiliki kemiripan tinggi. Pada penelitian ini kami juga membuktikan bahwa seluruh teknik differential modulation yang kami tawarkan mampu memberikan kinerja lebih baiik daripada Conventional Differential Modulation baik yang menggunakan channel coding ataupun tidak. Conventional Differential Modulation dengan convolutional coding dengan rate $1 / 2$ dan interleaver yang memiliki kompleksitas sistem tinggi mampu dikalahkan kinerjanya oleh Differential Unitary Modulation dengan Alamouti Matrix yang memiliki efisiensi spektrum frekuensi yang sama baik pada ketika menggunakan skema 1 maupun skema 2. Diantara teknik-teknik differential modulation yang kami teliti, Differential Unitary Modulation dengan OSTBC memiliki kinerja yang paling baik meskipun memiliki efisiensi spektrum yang paling rendah diantara yang lain, disusul Differential Unitary Modulation dengan QO-STBC yang bisa memberikan selisih kinerja kurang 
lebih $1 \mathrm{~dB}$ pada seluruh skema yang digunakan dan memiliki keunggulan dalam efisiensi spekrum dan kompleksitas dibandingkan dengan OSTBC. Secara umum konsep differential modulation yang kami tawarkan mampu menunjukkan kinerja yang baik untuk meningkatkan kualitas transmisi data pada kondisi ketika respon kanal berubah dengan cepat dikarenakan penggunaan pada kecepatan yang tinggi.

\section{DAFTAR RUJUKAN}

Alsifiany, F., Ikhlef, A., \& Chambers, J. (2017). On differential modulation in downlink multiuser MIMO systems. 25th European Signal Processing Conference, EUSIPCO 2017, 2017January, (pp. 558-562). https://doi.org/10.23919/EUSIPCO.2017.8081329

Althunibat, S., Mesleh, R., \& Basar, E. (2018). Differential Subcarrier Index Modulation. IEEE Transactions on Vehicular Technology, 678), 7429-7436. https://doi.org/10.1109/TVT.2018.2837691

Checko, A., Christiansen, H. L., Yan, Y., Scolari, L., Kardaras, G., Berger, M. S., \& Dittmann, L. (2015). Cloud RAN for Mobile Networks - A Technology Overview. IEEE Communications Surveys and Tutorials, 171), 405-426. https://doi.org/10.1109/COMST.2014.2355255

Ganesan, G., \& Stoica, P. (2002). Differential modulation using space-time block codes. IEEE Signal Processing Letters, 9(2), 57-60. https://doi.org/10.1109/97.991138

Gavrilovska, L., Rakovic, V., Ichkov, A., Todorovski, D., \& Marinova, S. (2017). Flexible C-RAN: Radio technology for 5G. 2017 13th International Conference on Advanced Technologies, Systems and Services in Telecommunications, TELSIKS 2017 Proceeding, 2017-October,

(pp.

255-264). https://doi.org/10.1109/TELSKS.2017.8246276

Hill, K. (2021, February 26). GSA: 61 countries have live 5 G networks - RCR Wireless News. Retrieved from www.rcrwireless.com.

Hofer, M., Šimko, M., Schwarz, S., \& Rupp, M. (2013). Performance evaluation of differential modulation in LTE - Downlink. International Conference on Systems, Signals, and Image Processing, 179-182. https://doi.org/10.1109/IWSSIP.2013.6623483

ITU-R. (2017). Minimum requirements related to technical performance for IMT-2020 radio interface(s) M Series Mobile, radiodetermination, amateur and related satellite services. http://www.itu.int/ITU-R/go/patents/en

Kumar, P. S., Sumithra, M. G., Abilash, R., \& Kumar, E. P. (2014). Performance analysis for differential STBC and SFBC MIMO- OFDM systems under different modulation schemes in a Rayleigh channel. 2014 International Conference on Electronics and 
Konsep Transmisi Tidak Koheren menggunakan Differential Unitary Modulation pada OFDMA

Communication Systems, ICECS 2014. https://doi.org/10.1109/ECS.2014.6892543

Martin, P. A. (2015). Differential Spatial Modulation for APSK in Time-Varying Fading Channels. IEEE Communications Letters, 19(7), 1261-1264. https://doi.org/10.1109/LCOMM.2015.2426172

Setiawan, D. P., \& Zhao, H.-A. (2018). Low-Complexity Differential Modulation for High Mobility MIMO-OFDM. IEICE Communications Express. https://doi.org/10.1587/comex.2018xbl0115

Setiawan, D. P., \& Zhao, H. A. (2019). A novel differential modulation scheme using full-rate STBC for $4 \times 4$ MIMO OFDM. International Journal of Electrical and Electronic

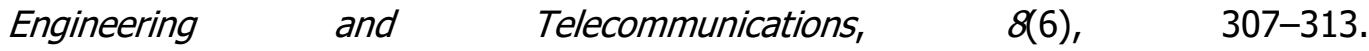
https://doi.org/10.18178/ijeetc.8.6.307-313

Sotiropoulos, N., Koonen, T., \& De Waardt, H. (2013). Advanced differential modulation formats for optical access networks. Journal of Lightwave Technology, 31(17), 28292843. https://doi.org/10.1109/JLT.2013.2267271

Tabbane, S. (2019). $4 G$ to $5 G$ networks and standard releases 1: CoE Training on Traffic engineering and advanced wireless network planning [PowerPoint Slides]. Retrieved from www.itu.int.

Tran, L. C., Mertins, A., \& Wysocki, T. A. (2013). Unitary differential space-time-frequency codes for MB-OFDM UWB wireless communications. IEEE Transactions on Wireless Communications, 12(2), 862-876. https://doi.org/10.1109/TWC.2012.122212.120436

Wei, R. Y., \& Wang, X. J. (2018). Differential 16-QAM and 16-APSK for Uplink Massive MIMO Systems. IEEE Wireless Communications Letters, 72$)$, 170-173. https://doi.org/10.1109/LWC.2017.2763143

Wen, M., Zheng, B., Kim, K. J., Di Renzo, M., Tsiftsis, T. A., Chen, K. C., \& Al-Dhahir, N. (2019). A Survey on Spatial Modulation in Emerging Wireless Systems: Research Progresses and Applications. IEEE Journal on Selected Areas in Communications, 379), 19491972. https://doi.org/10.1109/JSAC.2019.2929453 